\title{
DNA Base Sequence Homology in Rhizoctonia solani Kühn. VII. Genetic Relatedness between AG-BI and Other Anastomosis Groups
}

\author{
Shiro Kuninaga* and Ryozo Yokosawa*
}

\begin{abstract}
DNA base sequence homology between isolates of AG-BI and other anastomosis groups in Rhizoctonia solani was determined by DNA-DNA reassociation kinetics. A comparatively high homology was observed between AG-BI and AG-2. AG-BI isolates showed 36.1 to 48.0 $\%$ homology with isolate of AG-2-1 and 34.0 to $46.4 \%$ homology with isolates of AG-2-2. While, AG-BI isolates showed 18.7 to $30.2 \%$ homology with isolates in AG-3 and AG-6, but consistently low homology ( 0 to $14.4 \%$ ) with isolates in the other anastomosis groups. These results suggest that $\mathrm{AG}-\mathrm{BI}$ and $\mathrm{AG}-2$ should not be considered as separate groups. The phylogenetical relationship between $\mathrm{AG}-\mathrm{BI}$ and the groups of $\mathrm{AG}-2, \mathrm{AG}-3$ and $\mathrm{AG}-6$ is discussed.
\end{abstract}

(Received October 3, 1984)

Key Words : Rhizoctonia solani, anastomosis groups, DNA homology, genetic relatedness.

\section{Introduction}

In a previous paper ${ }^{11}$, it was demonstrated that each of the anastomosis groups (AGs) in Rhizoctonia solani Kühn is a genetically isolated group. This research also suggested that only $R$. solani isolates with similar gene structure successfully anastomose. Also, genetic recombinations through bridging between different AGs were not possible ${ }^{2)}$. However, there is a noteworthy exception to this rule as shown by the recent discovery of a group of "bridging isolates" (AG-BI) ${ }^{12)}$. Isolates of AG-BI not only anastomosed with isolates from this group, but also with isolates from AG-2, AG-3 and AG-6. Also AG-BI isolates show greater cultural and physiological similarity with isolates in $A G-2, A G-3$ and $A G-6$ than with isolates from other $\mathrm{AGs}^{13}$. Thus genetical relationships may exist between $A G-B I$ and these three $A G s$.

A previous study ${ }^{7)}$ provided evidence that $A G-B I$ comprises isolates genetically homogeneous. The purpose of this study was to determine DNA homology between AG-BI and other AGs on the basis of DNA-DNA reassociation kinetics and to elucidate genetical and evolutionary relationships among these AGs of $R$. solani. A preliminary report was published elsewhere ${ }^{10}$.

\section{Materials and Methods}

Isolate. Three isolates (TE2-4, SHC81 and KA1-1) of $R$. solani selected from AG-

* Department of General Education, Higashi Nippon Gakuen University, Onbetsu, Hokkaido 08801, Japan 東日本学園大学教養部 
BI and twelve isolates from eight other anastomosis groups were used. Origins of these isolates were described previously ${ }^{5-9}$.

DNA homology. Methods for fungal cultivation, preparation of DNAs, measurement of melting temperature (Tm) of DNAs, shearing of DNAs and determination of DNA fragment size as well as for calculation of DNA homology values were described in previous papers ${ }^{4,5)}$. DNA-DNA reassociation kinetics were observed in $5 \times$ SSC containing 20\% DMSO at a temperature about $25 \mathrm{C}$ below Tm.

\section{Results}

\section{DNA homology between AG-BI and other anastomosis groups}

Table 1 shows DNA homology values between isolates of AG-BI and the three groups (AG-2, AG-3 and AG-6) capable of anastomosis with AG-BI isolates. Comparatively high homology values (18.7 to 48.0\%) were observed between AG-BI and AG-2. AGBI isolates shared 36.1 to $48.0 \%$ homology with isolate of the winter crops type (II) in AG-2-1, 34.0 to $43.2 \%$ homology with isolate of the rush type (IIIB) in AG-2-2 and 38.9 to $46.4 \%$ homology with isolate of the root rot type (IV) in AG-2-2. Homology values between isolates of $\mathrm{AG}-\mathrm{BI}$ and $\mathrm{AG}-3$ ranged from 23.4 to $30.2 \%$. AG-BI isolates shared 23.7 to $29.1 \%$ homology with $\mathrm{HG}-\mathrm{I}$ isolate in AG-6 and 18.7 to $21.6 \%$ homology with GV isolate in AG-6. Fig. 1 and 2 illustrate the profiles of the DNA-DNA reassociation kinetics between DNAs from isolates of AG-BI and these three AGs.

Table 2 shows DNA homology values between isolates of AG-BI and the four groups (AG-1, AG-4, AG-5 and AG-7) not capable of anastomosis with AG-BI isolates. Consistently low homology values (0 to 14.4\%) were observed between $A G-B I$ and these AGs. AG-BI isolates shared 0 to $9.2 \%$ homology with isolate of the sasakii type (IA) in $\mathrm{AG}-1$ and 1.8 to $14.1 \%$ homology with isolate of the web-blight type (IB) in AG-1. AG-BI isolates shared 0 to $6.0 \%$ homology with $\mathrm{HG}-\mathrm{I}$ isolate in AG-4 and 0 to $7.6 \%$

Table 1. DNA homology between isolates of AG-BI and the groups of AG-2, AG-3 and AG-6 in Rhizoctonia solani

\begin{tabular}{|c|c|c|c|c|}
\hline \multirow{2}{*}{ Isolate } & \multicolumn{3}{|c|}{$\mathrm{AG}-\mathrm{BI}$} & \multirow{2}{*}{ Range } \\
\hline & (TE2-4) & (SHC81) & $(\mathrm{KA} 1-1)$ & \\
\hline$A G-2-1^{\text {a) }}, I I^{\text {b) }} \quad(\mathrm{R} 123)$ & $36.1-47.3^{\mathrm{d})}$ & $40.1-48.0$ & $37.2-42.7$ & $36.1-48.0$ \\
\hline AG-2-2, IIIB $\quad$ (B 60) & $33.9-41.0$ & $34.0-37.3$ & $36.2-43.2$ & $33.9-43.2$ \\
\hline $\mathrm{AG}-2-2, \mathrm{IV} \quad(\mathrm{BR}-2)$ & $38.9-42.3$ & $39.1-46.0$ & $39.8-46.4$ & $38.9-46.4$ \\
\hline $\mathrm{AG}-3, \mathrm{IV} \quad$ (ST 3-1) & $23.9-29.0$ & $24.0-28.7$ & $23.4-30.2$ & $23.4-30.2$ \\
\hline $\left.\mathrm{AG}-6, \mathrm{HG}-\mathrm{I}^{\mathrm{c}}\right)(\mathrm{AT} 2-1)$ & $25.6-29.1$ & $23.7-26.8$ & $24.8-28.8$ & $23.7-29.1$ \\
\hline $\mathrm{AG}-6, \mathrm{GV} \quad(\mathrm{NKN} 2-1)$ & $19.1-20.6$ & $18.7-21.1$ & $19.8-21.6$ & $18.7-21.6$ \\
\hline
\end{tabular}

a) Anastomosis group (Ogoshi, 1976) ${ }^{16)}$.

b) Cultural type (Watanabe \& Matsuda, 1966)22).

c) Kuninaga \& Yokosawa $(1984)^{9)}$.

d) The range of homology values is the result of two or three determinations. Homology values were calculated from the equation by Seidler \& Mandel (1971) ${ }^{18)}$. 

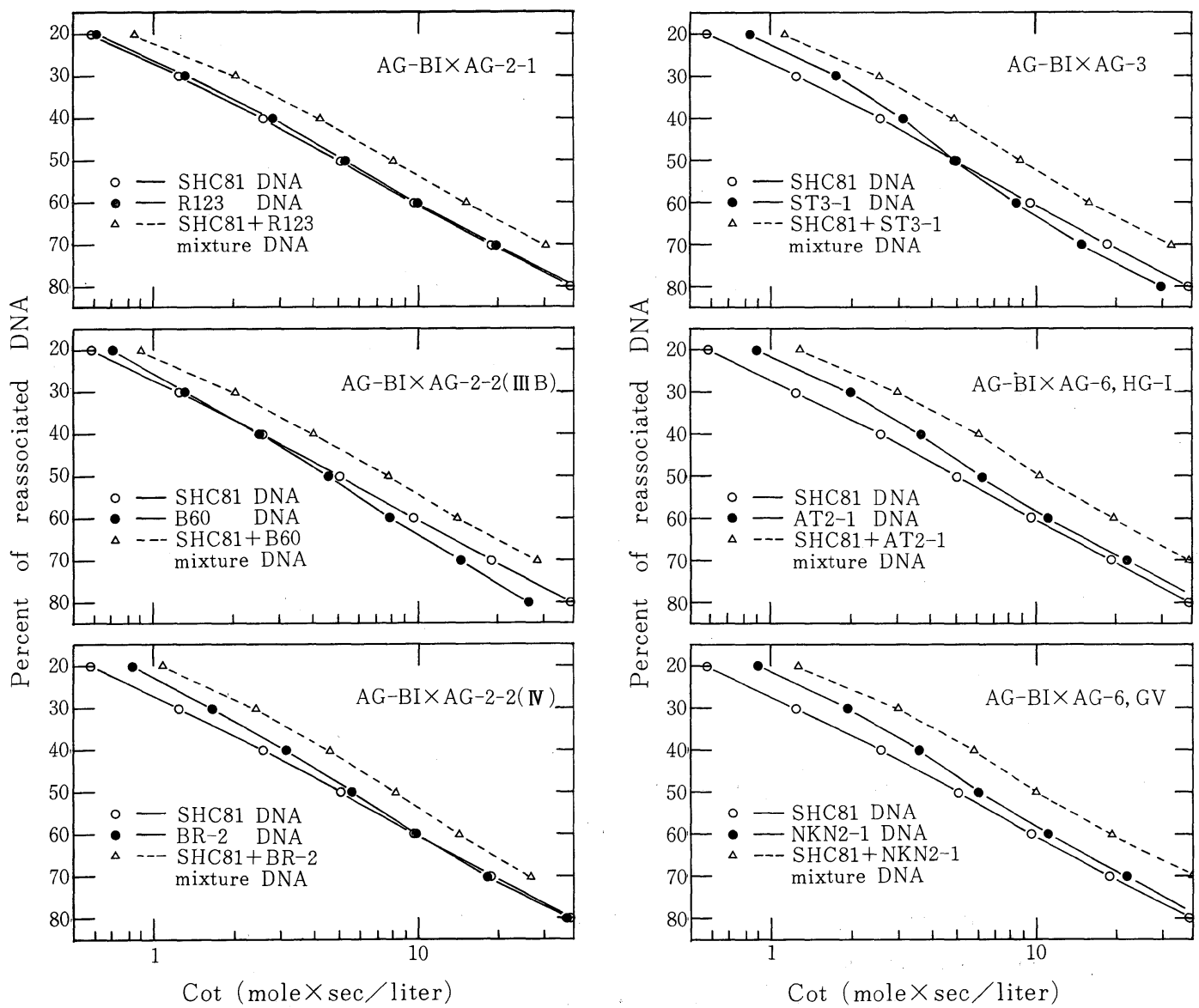

Fig. 1. Reassociation kinetics of the mixture of DNA from isolates of AG-BI and AG-2 in Rhizoctonia solani. All reactions were carried out in $5 \times \mathrm{SSC}$ containing $20 \%$ DMSO at $62 \mathrm{C}$ (left).

Fig. 2. Reassociation kinetics of the mixture of DNA from isolates of AG-BI and the groups of AG-3 and AG-6 in Rhizoctonia solani. All reactions were carried out in $5 \times \mathrm{SSC}$ containing $20 \% \mathrm{DMSO}$ at $62 \mathrm{C}$ (right).

Table 2. DNA homology between isolates of $A G-B I$ and the groups of $A G-1, A G-4$, $\mathrm{AG}-5$ and $\mathrm{AG}-7$ in Rhizoctonia solani

\begin{tabular}{|c|c|c|c|c|c|}
\hline \multirow{2}{*}{\multicolumn{2}{|c|}{ Isolate }} & \multicolumn{3}{|c|}{$\mathrm{AG}-\mathrm{BI}$} & \multirow{2}{*}{ Range } \\
\hline & & $(\mathrm{TE} 2-4)$ & \multirow{2}{*}{$\frac{(\mathrm{SHC} 81)}{5.9-9.2}$} & \multirow{2}{*}{$\frac{(\mathrm{KA} 1-1)}{3.1-8.8}$} & \\
\hline$A G-1^{a)}, I^{b}{ }^{b}$ & $(A-10)$ & $0-3.1^{\mathrm{d})}$ & & & $\begin{array}{ll}0 & -9.2\end{array}$ \\
\hline $\mathrm{AG}-1, \mathrm{IB}$ & $(001-7)$ & $7.0-12.0$ & $1.8-3.0$ & $7.6-14.1$ & $1.8-14.1$ \\
\hline $\mathrm{AG}-4, \mathrm{HG}-\mathrm{I}^{\mathrm{c})}$ & $(\mathrm{Chr}-3)$ & $0-3.8$ & $4.2-6.0$ & $1.3-4.4$ & $0-6.0$ \\
\hline $\mathrm{AG}-4, \mathrm{HG}-\mathrm{II}$ & (UHBC) & $0-5.6$ & $2.2-7.6$ & $2.5-7.4$ & $0-7.6$ \\
\hline$A G-5$ & $(\mathrm{TE} 1-5)$ & $6.7-9.3$ & $5.0-13.9$ & $6.2-14.4$ & $5.0-14.4$ \\
\hline$A G-7$ & (1535) & $5.2-7.6$ & $0-5.8$ & $6.2-14.4$ & $\begin{array}{ll}0 & -14.4\end{array}$ \\
\hline
\end{tabular}

a), b), d) See footnote in Table 1 .

c) Kuninaga \& Yokosawa $(1984)^{8}$. 


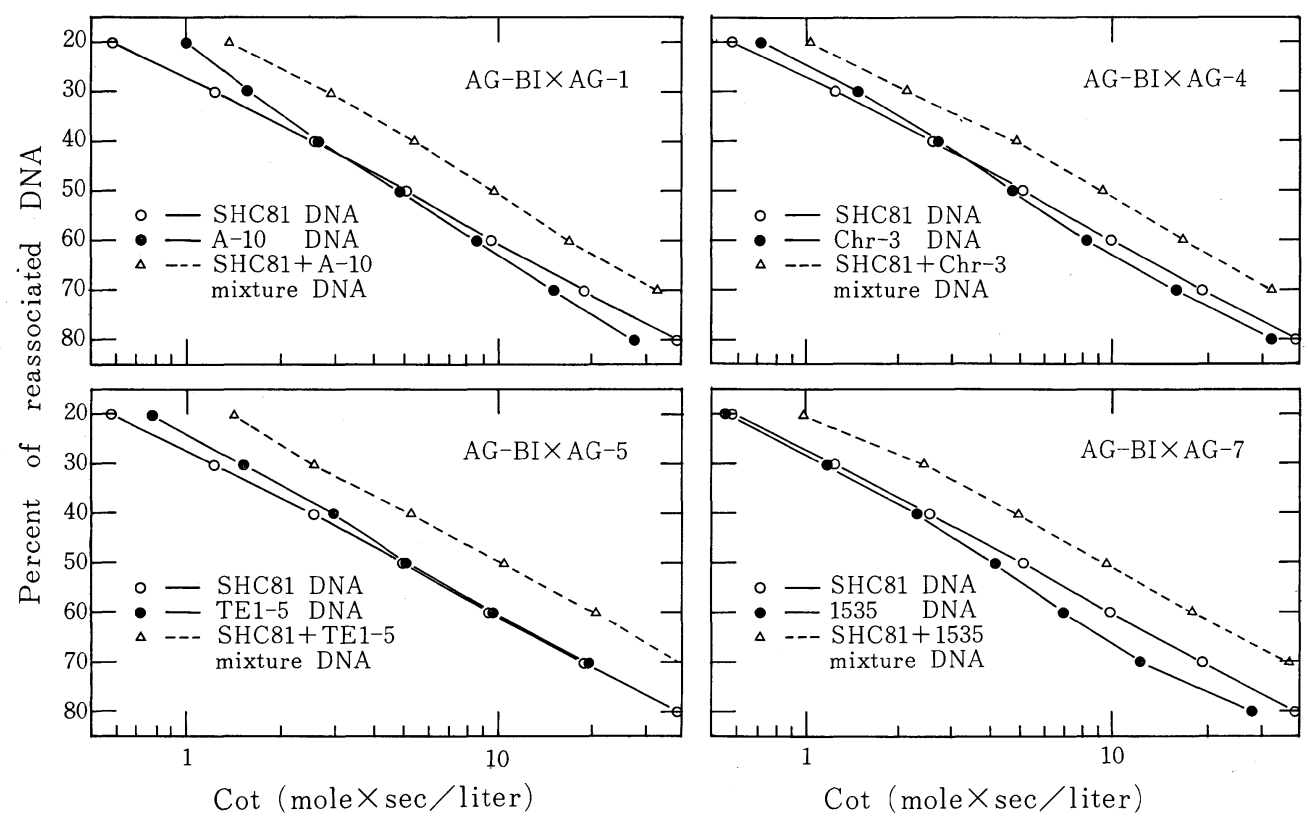

Fig. 3. Reassociation kinetics of the mixture of DNA from isolates of $\mathrm{AG}-\mathrm{BI}$ and the groups of AG-1, AG-4, AG-5 and AG-7 in Rhizoctonia solani. All reactions were carried out in $5 \times \mathrm{SSC}$ containing 20\% DMSO at $62 \mathrm{C}$.

homology with HG-II isolate in AG-4. Homology values between isolates of AG-BI and AG-5 ranged from 5.0 to $14.4 \%$, and homology between isolates of AG-BI and AG-7 ranged from 0 to $14.4 \%$. Fig. 3 shows the reassociation kinetics between DNAs from isolates of $\mathrm{AG}-\mathrm{BI}$ and these four $\mathrm{AGs}$.

\section{Discussion}

This study demonstrated that AG-BI isolates show comparatively high DNA homology (18.7 to 48.0\%) with isolates of AG-2, AG-3 and AG-6 which are capable of anastomosis with AG-BI isolates, whereas markedly low DNA homology (0 to 14.4\%) with isolates of $A G-1, A G-4, A G-5$ and $A G-7$ which are not capable of anastomosis with AG-BI isolates. These findings suggest that anastomosis behaviour of the "bridging isolates" in AG-BI could provide information on genetical and evolutionary relationships among AGs in $R$. solani

In a previous paper ${ }^{11}$, it was stated that isolates of $R$. solani with more than about 30 to $35 \%$ homology should be regarded as belonging to the same AG. As judged from this criteria, it is suggested that AG-BI and AG-2, showing 34.0 to $48.0 \%$ homology, should not be considered as separate groups. AG-BI isolates also show a relatively high frequence of anastomosis with AG-2 isolates ${ }^{13)}$. Such phenomena and the results of DNA homology led to the conclusion that evolutionary changes between isolates in AG-BI and AG-2 still were not completed, and that AG-2 might have phylogenetically originated 
from AG-BI. These assumptions are also supported by the observations of cultural and physiological similarity between both groups ${ }^{12,13)}$. It was also reported that within AG2 two subgroups (AG-2-1 and AG-2-2), showing different frequency of anastomosis, can be distinguished ${ }^{11)}$. Various degrees of anastomosis frequency observed in AG-BI and AG-2 may have played a significant role in their evolution. Whether outbreeding is possible between these groups is a problem yet to be solved in this context.

In this study, consistently low homology (less than 30\%) was observed between isolates of AG-BI and other AGs except AG-2. This suggests that AG-BI is genetically isolated from these AGs with the exception of AG-2. On the other hand, AG-BI isolates showed somewhat higher homology (18.7 to 30.2\%) with isolates of AG-3 and AG-6 than that with isolates of AG-1, AG-4, AG-5 and AG-7. These results and the observations $^{13)}$ that $A G-B I$ isolates can anastomose (but very rarely do) with isolates of $A G-3$ and AG-6 lead us to speculate on evolutionary close relationships among these AGs. It appears that AG-3 and AG-6 may be populations which have evolved from AG-BI.

Storck \& Alexopoulos ${ }^{19)}$ suggested that the evolution of fungi is usually accompanied by a progressive increase in GC content of DNA. Similar correlation between GC content and evolution was also found among bacteria in the actinomycetes ${ }^{3,19)}$ and also among intragenetic variations of yeasts ${ }^{15,19,20)}$. Indeed, AG-BI isolates showed the lowest GC content among all isolates of AGs in R. solanis). This further supports the assumption that AG-2, AG-3 and AG-6 may have evolved from AG-BI. AG-BI isolates are avirulent ${ }^{12)}$, whereas isolates of $A G-2$ and $A G-3$ exhibit parasitic features ${ }^{1,16,17)}$. This suggests that evolutionary changes of $R$. solani are accompanied by the progressive specialization of parasitic habits. This seems to give a proof of the direction of evolutionary series toward parasitism in plant pathogenic fungi ${ }^{14,21,23)}$. Further studies on genomic analysis of $R$. solani would be useful for elucidating these interesting question.

The authors are grateful to Dr. A. Ogoshi, Hokkaido University, Dr. N. A. Anderson, Minnesota University and Dr. R. Baker, Colorado State University, for critical reading of this manuscript.

\section{Literature cited}

1. Anderson, N. A. (1982). Ann. Rev. Phytopathol. $20: 329-347$.

2. Bolkan, H. A. (1976). Fitopatol. Bras. $1: 14-17$.

3. Hill, L. R. (1966). J. Gen. Microbiol. $44: 419-437$.

4. Kuninaga, S. and Yokosawa, R. (1980). Ann. Phytopath. Soc. Japan 46:150-158.

5. Kuninaga, S. and Yokosawa, R. (1982). Ibid. 48:659-667.

6. Kuninaga, S. and Yokosawa, R. (1982). Ibid. $48: 668-673$.

7. Kuninaga, S. and Yokosawa, R. (1983). Ibid. $49: 647-652$.

8. Kuninaga, S. and Yokosawa, R. (1984). Ibid. $50: 322-330$.

9. Kuninaga, S. and Yokosawa, R. (1984). Ibid. $50: 346-352$.

10. Kuninaga, S. and Yokosawa, R. (1984). Ibid. $50: 398$ (Abstr.).

11. Kuninaga, S. and Yokosawa, R. (1985). Ibid. 51:127-132.

12. Kuninaga, S., Yokosawa, R. and Ogoshi, A. (1978). Ibid. $44: 591-598$ (In Japanese).

13. Kuninaga, S., Yokosawa, R. and Ogoshi, A. (1979). Ibid. $45: 207-214$ (In Japanese).

14. McNew, G. L. (1960). In Plant Pathology, An Advanced Treatise (Horsfall, J. G. and Dimond, A. E. eds.), Vol. 2, Academic Press, New York. pp. 20-70.

15. Nakase, T. and Komagata, K. (1968). J. Gen. Appl. Microbiol. 14:345-357.

16. Ogoshi, A. (1976). Bull. Natl. Inst. Agric. Sci. Series C. 30:1-63 (In Japanese). 
17. Parmeter, J. R. Jr., Sherwood, R. T. and Platt, W. D. (1969). Phytopathology 59: 1270-1278.

18. Seidler, R. and Mandel, M. (1971). J. Bacteriol. 608-614.

19. Storck, R. and Alexopoulos, C. J. (1970). Bacteriol. Rev. 34:126-154.

20. Storck, R., Alexopoulos, C. J. and Phaff, H. J. (1969). J. Bacteriol. $91: 227-230$.

21. Ui, T. (1973). Rev. Plant Protec. Res. $6: 115-131$.

22. Watanabe, B. and Matsuda, A. (1966). Appointed Experiment (Plant Disease and Insect Pests). No. 7, Agriculture, Forestry and Fishery Research Council, and Ibaragi Agric. Exp. Stn. pp. 131 (In Japanese).

23. Wheeler, B. E. J. (1968). In The Fungi, An Advance Treatise (Ainsworth, G. C. and Sussman, A. S. eds.), Vol. 3, Academic Press, New York and London. pp. 179-210.

\section{和 文 摘 要}

国永史朗・横沢菱三：Rhizoctonia solani 飞おける DNA 塩基配列の相同性ＶII. AG-BI と他の菌系融合 群間の遺伝的類縁性

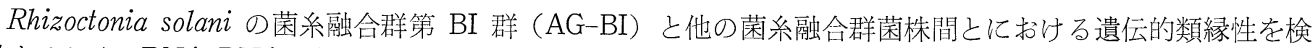
討するため, DNA-DNA 再会合反応速度解析に基づき DNA 塩基配列の相同性を比較した。AG-BI は AG -2 と比較的高い相同性（34.0 48.0\%) を示し，また AG-3 および AG-6 とでは18.7〜 30.2\%相同性を示し たが，その他の菌系融合群とでは，いずれの場合も著しく低い相同性を示した（０１4.4\%)。DNA 相同性 比較結果から, AG-BI と AG-2 は相互に遺伝的に近縁なグループであるととが示唆され，また AG-BI と AG-3 抒よび AG-6 の菌系融合群間に系統発生的な関係が認めら机た。 